\title{
Editorial: Pathogenesis of retinopathy in malignant hypertension
}

The clinical features of retinopathy in Bright's disease were clearly described by Liebreich (1859) many years before the association with high blood pressure was recognized. Bull, writing in 1886 , appears to have been the first to recognize that these features carried a very poor prognosis; twothirds of his patients with papilloedema died within a year. Following the invention of practical sphygmomanometers in the latter part of the 19th century and the discovery of the auscultatory method of taking blood pressure in 1905 by Korotkow, the association of retinopathy with severe elevation of blood pressure became well known. Marcus Gunn (1898) and Foster Moore (I916) published accurate clinical descriptions of the arterial and crossing changes in hypertension, and Volhard and Fahr (1914) proposed that the connection between renal disease, hypertension, and retinopathy lay in "angio-spasm". The work of Keith, Wagener, and Barker (1939) led to a general acceptance among physicians and ophthalmologists that retinal examination was a vital part of the clinical assessment of the severity of hypertensive vascular disease, and one of the most accurate ways of predicting the outcome.

Later, it became apparent that there were unsatisfactory features of the Keith-Wagener classification. Kagan, Aurell, and Tibblin (1967) derived a quantitative measure of arterial narrowing and straightening in hypertension and took precautions against observer bias. Although the mean widths of the vessels in individuals whose diastolic pressure exceeded $120 \mathrm{~mm} . \mathrm{Hg}$ was only 83 per cent. of that in patients with a diastolic pressure below $79 \mathrm{~mm} . \mathrm{Hg}$, there was a substantial overlap between the two groups. van Buchem, van der Heuvel-Aghina, and van der Heuvel (1964) showed that changes in light reflex and crossing changes are common in normotensive men in later life. Despite these doubts concerning the validity of the first two grades of the Keith-Wagener classification, the prognostic significance of the third and fourth grades has rarely been doubted. Published series from many different parts of the world show that about 90 per cent. of patients with haemorrhages, exudates, and papilloedema will die within a year if they are not treated (Kincaid-Smith, McMichael, and Murphy, 1958).

However, Pickering (1955) has argued persuasively that cotton-wool spots and linear haemorrhages are of much greater significance than blot haemorrhages and hard exudates in the hypertensive fundus. Attention has thus been focused upon the prognostic significance and pathogenesis of the cotton-wool spots

Ten years ago, workers at the Institute of Ophthalmology and the Royal Postgraduate Medical School began a collaborative study of the cotton-wool spot in hypertension and their latest joint publication appears in this issue of the British Fournal of Ophthalmology. The most prominent feature of fluorescence angiograms in patients with untreated malignant hypertension is leaking points on minute arteries. Points of leakage of fluorescein are always found upon the arteries supplying the area occupied by cottonwool spots, and capillary perfusion in that area is usually diminished or absent (Hodge and Dollery, 1964). Pathological studies have shown that cottonwool spots are retinal infarcts caused by arterial obstruction and can be produced experimentally in cats and pigs by embolizing the retinal arteries (Ashton, Dollery, Henkind, Hill, Paterson, Ramalho, and Shakib, ig66).

Doubt remained about the mechanisms involved in the causation of leaking points and focal retinal ischaemia in malignant hypertension. The availability of an excellent experimental model for human malignant hypertensive retinopathy in the Cynomolgus monkey has enabled much new evidence to be accumulated (Ashton, Peltier, and Garner, 1968). The fluorescence angiograms of these animals show many points of focal leakage of fluorescein from small arteries and, at a later stage, arterial obstruction. The pathological changes of the vessels include extreme narrowing, smudgy necrosis of smooth muscle cells, dilatation, and penetration of plasma with later deposition of fibrin in the wall.

The sequence in which these changes take place is of crucial importance in interpreting their pathogenesis. The fluorescence angiograms suggest that focal leakage precedes severe ischaemia with cottonwool spot formation, while the pathological studies show vessel closure to be a prominent feature even at an early stage. However, vessel closure is difficult to interpret as the vessels were fixed after the circulation had been interrupted. Meanwhile there has been a resurgence of interest in the vascular changes of malignant hypertension amongst research workers studying other vascular beds, such as the mesentery and the brain. Four main theories have been propounded to explain the origins of the vessel changes: angio-spasm, autoregulatory failure, a humoral vascular damaging factor, and disseminated intravascular coagulation.

The normal response of a vessel to a rising intraluminal pressure is to constrict, probably to keep 
flow in the vascular bed constant; this phenomenon is termed "autoregulation". If the pressure rises high enough, the vessel's resistance is eventually overcome and it dilates. As the vessel gives way at the point of autoregulatory failure, it becomes widely dilated, the wall is stretched by the high distending pressure, flow increases, and plasma constituents penetrate the wall (Goldby and Beilin, 1972a,b; Strandgaard, Olesen, Skinhøj, and Lassen, I973). It is not certain whether the phase of constriction or "angio-spasm" before the break-point is reached can be severe enough to cause focal ischaemia. If its purpose is autoregulation, constriction severe enough to cause ischaemia would seem inappropriate.

Evidence for a humoral vascular damaging factor in human malignant hypertension is scanty and indirect. Brunner, Laragh, Baer, Newton, Goodwin, Krakoff, Bard, and Buhler (1972) suggested that renin, or the angiotensin it produced, might damage blood vessels and predispose to cerebral and myocardial infarction but their findings have yet to be generally accepted. In animals, Gavras, Brown, Lever, MacAdam, and Robertson (197I) showed that high doses of renin could lead to renal failure and myocardial infarction but here again the relevance to human hypertension is still an open question.

Vascular damage is often associated with fibrin degradation products in the plasma and red cell fragmentation in "microangiopathic haemolytic anaemia". These features are present in many patients with malignant hypertension (Brain and Hourihane, 1967). Gavras, Brown, Brown, Lever, Linton, MacAdam, McNicol, Robertson, and Wardrop (I97I) have suggested that disseminated intravascular coagulation plays a role in the pathogenesis of the vascular lesions of malignant hypertension but it is equally likely to be a consequence of them.

Autoregulatory failure seems to explain certain otherwise puzzling features. An abrupt rise in pressure will precipitate malignant hypertension at a lower level than will a gradual rise. Compensatory smooth muscle hypertrophy which renders the vessel wall better able to withstand the pressure and shifts the break-point higher is a reasonable explanation. Possibly Leishman (1957) was correct when he supposed that an ageing vessel was better able to withstand the bursting stress and thus less likely to allow hypertension to enter a malignant phase.

Neither explanation rules out the possibility that humoral or neurogenic factors may modify the breakpoint. For example, anaemia, which requires that the vessel should be widely dilated to meet metabolic needs, might lower the break-point because the distal vessel is thereby exposed to a higher pressure. Young patients with renal failure who enter the malignant phase very readily often have both an abrupt rise in pressure and severe anaemia. This hypothesis might also explain the causation of cotton-wool spots at a normal blood pressure in cases of severe anaemia.

\section{References}

AShton, N., Dollery, G. T., henkind, P., hill, D. W., PAterson, J. W., RAmalho, P. S., and shakib, M. (1966)

Brit. J. Ophthal., 50, 281

- PEltier, s., and Garner, A. (I968) Trans. ophthal. Soc. U.K., 88, 167

Brain, M. G., and hourihane, D.o'B. (1967) Brit. J. Haemat., 13, I 35

BRUNNER, H. R., LARAGH, J. H., BAER, L., NEWTON, M. A., GOODWIN, F. T., KRAKOFF, L. R., BARD, R. H., and

BUHLER, F. R. (1972) New Engl. F. Med., 286, 44 I

Buchem, F. S. P. VAN, heUVel-Aghina, J. W. M. T. VAN Der, and heuVel, J. E. A. VAN Der (1964) Acta med.

scand., I 76, 539

BUll, G. S. (1886) Trans. Amer. ophthal. Soc., 4, 184

GAVRAS, H., BROWN, J. J., LEVER, A. F., MACADAM, R. F., and ROBERTSON, J. I. s. (I97 I) Lancet, 2, I9

-, BROWN, W. G., BROWN, J. J., LEVER, A. F., LINTON, A. L., MACADAM, R. F., MCNiCOL, G. P., ROBERTSON,

J. I. s., and WARdrop, C. (I97I) Circ. Res., 28, Suppl. 2, p. 127

GOLDBY, F. S., and BEILIN, L. J. (I972a) Cardiovasc. Res. 6, 569

(1972b) Ibid., 6, 384

GUNN, M. (1898) Trans. ophthal. Soc. U.K., 18, 356

HODGE, J. v., and DOLleRY, c. T. (1964) Quart. F. Med., 33, I I 7

kAGAN, A., AURELl, E., and tibBlin, G. (1967) Bull. WHO, 36, 231

Keith, N. M., WAgener, H. P., and barker, N. w. (1939) Amer. F. med. Sci., 197, 332

KINGAID-SMITH, P., MCMIGHAEL, J., and MURPHY, E. A. (1958) Quart. F. Med., 27, I I 7

Korotkow, N. s. (1905) Izvest. imp. voyenno-med. Akad. St. Petersburg, 1 1, 365

LEISHMAN, R. (1957) Brit. J. Ophthal., 41, 641

LIEBREICH, R. (1859) v. Graefes Arch. Ophthal., 5, 265

MOORE, R. FOSTER (1916) Quart. F. Med., ro, 29

PICkering, G. W. (I955) "High Blood Pressure". Churchill, London

STRANDGAARD, s., OLESEN, J., SkINHøJ, E., and LASSEN, N. A. (1973) Brit. med. F., 1, 507

VOLHARD, F., and FAHR, K. T. (1914) "Die Brightische Nierenkrankheit". Springer, Berlin 